\title{
POTENSI REDUKSI LIMPASAN PERMUKAAN DENGAN METODE SOIL CONSERVATION SERVICE - CURVE NUMBER DI KELURAHAN RAWA BUNTU
}

\author{
Steffanny Trifenaa ${ }^{a}$ Dwi Prabowo ${ }^{b}$ \\ aUniversitas Surya; F8 \& F9 Grand Serpong Mall Jalan MH. Thamrin Panunggangan Utara Pinang, \\ Tangerang Banten 15143; \\ bUniversitas Semarang; Jl. Soekarno Hatta, Tlogosari Kulon, Kec. Pedurungan, Kota Semarang, Jawa Tengah 59160; \\ dwiprabowo@usm.ac.id
}

Info Artikel:

- Artikel Masuk: 13/09/2020

- Artikel diterima: $28 / 10 / 2020$

- Tersedia Online: 30/10/2020

\begin{abstract}
ABSTRAK
Perkembangan pembangunan di Kelurahan Rawa Buntu menyebabkan perubahan tata guna lahan dan membuat luas RTH di Kelurahan Rawa Buntu semakin berkurang, sehingga dapat menyebabkan terjadinya banjir. Penelitian ini dilakukan untuk dapat mengetahui potensi reduksi limpasan air hujan pada setiap jenis tutupan lahan yang ada di Kelurahan Rawa Buntu untuk dijadikan sebagai dasar perencanaan yang lebih baik di masa depan. Metode Soil Conservation Service - Curve Number (SCS-CN) digunakan untuk menghitung total limpasan air hujan yang dapat direduksi dan mengetahui peranan dari RTH dalam mereduksi limpasan air hujan. Hasil penelitian menunjukkan bahwa kawasan permukiman mendominasi wilayah Kelurahan Rawa Buntu sekitar 65\% dan luas RTH hanya sekitar 18\%. Volume limpasan air hujan yang dapat direduksi setiap bulannya pada kondisi AMC I, AMC II, dan AMC III adalah 74,4MGal, 37,8MGal, dan 17,9MGal dengan kontribusi RTH sebesar 27\%, 31,2\%, dan 36,4\% dari total limpasan air hujan yang dapat direduksi untuk masing-masing kondisi AMC.
\end{abstract}

Kata Kunci : RTH, Limpasan Air Hujan, SCS-CN, Kelurahan Rawa Buntu, Tutupan Lahan

\section{ABSTRACT}

Development in Rawa Buntu Subdistrict caused land use change and made green space area in Rawa Buntu Subdistrict decreased, so it could cause flood. This research was conducted to know the potential of rainwater runoff reduction in each type of land cover in Rawa Buntu Subdistrict to serve as the basis for better planning in the future. The Soil Conservation Service - Curve Number (SCS-CN) method is used to calculate the total rainfall runoff that can be reduced and to know the role of green space in reducing rainwater runoff. The result of the research shows that residential area dominates Rawa Buntu Subdistrict about $65 \%$ and green space is only about $18 \%$. The volume of rainfall runoff that can be reduced each month on AMC I, AMC II and AMC III is 74,4MGal, 37,8MGal and 17,9MGal with green space contribution of $27 \%, 31,2 \%$ and $36,4 \%$ of the total rainfall runoff that can be reduced for each $A M C$ condition.

Keyword: Green Space, Rainwater Runoff, SCS-CN, Rawa Buntu Subdistrict, Land Cover

\section{PENDAHULUAN}

Seiring dengan perkembangan wilayah perkotaan di Indonesia, Kota Jakarta sebagai ibukota mengalami pertumbuhan penduduk yang cukup signifikan dari tahun ke tahun. Menurut Badan Pusat Statistik (BPS) DKI Jakarta, pertumbuhan penduduk Jakarta terus mengalami peningkatan dari tahun 2002-2016 dengan pertumbuhan rata-rata lebih besar dari 100.000 penduduk setiap tahunnya. Penelitian Khaqim (2013) juga menunjukkan bahwa proyeksi pertumbuhan penduduk DKI Jakarta meningkat 3\% setiap tahun dan diperkirakan populasinya akan mencapai 142,5 juta orang pada tahun 2105 mendatang. Pertumbuhan penduduk akibat urbanisasi yang terjadi di Jakarta tersebut menyebabkan Jakarta tidak dapat lagi menampung penduduk baru, terutama terkait dalam hal penyediaan tempat tinggal yang memadai bagi warganya. Hal ini menyebabkan banyak bangunan liar dan masalah lain yang terjadi di Jakarta.

Pesatnya perkembangan Kota Jakarta ini mendorong perkembangan wilayah perkotaan lain di sekitarnya. Kecamatan Serpong merupakan salah satu wilayah yang dijadikan sebagai salah satu daerah penyanggah bagi ibukota Jakarta dan memiliki fungsi penting untuk mendukung kegiatan di Jakarta supaya dapat berjalan dengan baik. Secara administratif, kecamatan yang terletak di bagian Selatan Kabupaten Tangerang ini terdiri dari 9 kelurahan, 112 Rukun Warga $(\mathrm{RW})$, dan 486 Rukun Tetangga (RT) dengan 
luas wilayah sebesar $24,04 \mathrm{~km} 2$ atau meliputi $16,33 \%$ dari total luas Kota Tangerang Selatan.

Pertumbuhan penduduk yang pesat pada wilayah perkotaan umumnya berujung pada banyak terjadinya perubahan tata guna lahan di wilayah perkotaan. Pada setiap wilayah perkotaan, pasti terdapat ruang terbuka hijau (RTH) yaitu area memanjang/jalur dan/atau mengelompok, yang penggunaannya lebih bersifat terbuka, tempat tumbuh tanaman, baik yang tumbuh secara alamiah maupun yang sengaja ditanam (UU RI No. 26 Tahun 2007). Kelurahan Rawa Buntu terletak pada lokasi yang cukup strategis karena memiliki stasiun kereta api yang dapat menghubungkan wilayah tersebut dengan ibukota Jakarta. Hal ini mengakibatkan kelurahan ini menjadi padat penduduk. Jumlah penduduk yang terus meningkat dari tahun ke tahun inilah yang mendorong pembangunan terus dilakukan pada wilayah ini, walaupun sebenarnya sudah tidak ada lagi lahan yang tersedia. Kondisi ini menjadi pemicu terjadinya alih fungsi lahan yang sebelumnya diperuntukan untuk RTH, sekarang diubah menjadi kawasan permukiman. Selain itu, alih fungsi lahan RTH di Kelurahan Rawa Buntu juga secara tidak langsung terjadi akibat perekonomian daerah yang semakin meningkat. Masyarakat yang tinggal di Kelurahan Rawa Buntu ini cenderung menghilangkan $\mathrm{RTH}$ privat seperti halaman rumah yang sebelumnya ada pada tempat tinggal mereka. Perekonomian yang semakin baik menyebabkan masyarakat setempat melakukan renovasi pada rumah mereka, serta menghilangkan dan mengganti RTH mereka menjadi garasi dan teras rumah atau permukaan yang kedap air (impermeable surface), sehingga tidak dapat meresapkan air ke dalam tanah. Akibatnya, pada beberapa tahun belakangan ini Badan Penanggulangan Bencana Daerah Kota Tangerang Selatan (BPBD Kota Tangsel) mencatat terdapat beberapa peristiwa timbulnya genangan air di Kelurahan Rawa Buntu pada saat hujan terjadi akibat tidak terserapnya limpasan air hujan (run off) dengan baik, antara lain sering terjadi pada wilayah Kampung Serpong, Kantor Kelurahan Rawa Buntu, jalan raya sekitar perumahan De Latinos, dan lain sebagainya. Kelurahan
Rawa Buntu memerlukan adanya perencanaan tata guna lahan dan ketersediaan RTH yang baik supaya dapat meminimalkan terjadinya risiko- risiko yang tidak diinginkan. Oleh karena itu, studi awal perhitungan besarnya volume air limpasan (run off) yang dapat direduksi pada wilayah Kelurahan Rawa Buntu sangat diperlukan untuk dapat menjadi dasar dalam menentukan strategi perencanaan yang baik pada wilayah Kelurahan Rawa Buntu. Penelitian studi awal limpasan ini dapat dilakukan dengan metode Soil Conservation Service - Curve Number (SCS-CN), dimana penelitian ini dapat melihat besarnya volume limpasan air hujan (run off) yang dapat direduksi pada wilayah Kelurahan Rawa Buntu berdasarkan karakteristik tutupan lahan yang ada pada wilayah tersebut. Metode SCS-CN juga dapat menjelaskan hubungan antara curah hujan dengan limpasan permukaan, serta dapat dilakukan dalam waktu yang relatif efektif dan cepat, sehingga tidak terlalu memerlukan waktu dan biaya penelitian yang banyak. Pada akhir dari penelitian ini juga dapat dilihat seberapa penting peran RTH pada Kelurahan Rawa Buntu untuk dapat mereduksi jumlah limpasan (run off) di wilayah tersebut dibandingkan dengan tutupan lahan lainnya.

Apabila sudah diketahui jumlah limpasan permukaan yang dapat direduksi di suatu wilayah penelitian pada kondisi saat ini, maka perencanaan penanganan limpasan di wilayah tersebut dapat dilakukan secara lebih terukur dan detail. Misalnya, salah satu manfaat dari penelitian dapat diaplikasikan pada pembangunan drainase untuk masa yang akan datang. Penelitian ini dapat dijadikan acuan berapa besar volume drainase yang perlu dipersiapkan, sehingga perencanaan pembangunan drainase pada wilayah tersebut pun akan lebih optimal.

\section{DATA DAN METODE}

Secara umum, penurunan total limpasan oleh ruang terbuka hijau (RTH) di Indonesia masih diukur dengan kecepatan infiltrasi air ke dalam tanah untuk masing-masing RTH yang ada atau dengan melakukan pemodelan 52 
hidrologi (Andini, 2016; Harisuseno, 2014; Permanasari, 2012). Namun, penggunaan metode untuk mengukur tingkat infiltrasi dan pemodelan membutuhkan waktu yang lama karena kompleksitas daerah penelitian, dimana pengukuran harus diambil dari setiap RTH yang ada di daerah penelitian. Oleh karena itu, dalam penelitian ini akan digunakan metode SCS-CN untuk mengukur kapasitas total limpasan yang dapat direduksi pada wilayah penelitian. Hal yang menjadi pertimbangan utama dipilinnya metode ini adalah lebih sederhana dan dapat dilakukan dengan cepat untuk setiap lokasi penelitian karena sudah memiliki database nilai koefisien CN untuk setiap jenis tutupan lahannya. Penelitian ini merupakan jenis penelitian deskriptif karena mengumpulkan data-data yang representatif untuk menjelaskan tentang suatu subjek yang sedang diteliti. Metode SCSCN juga telah sering digunakan untuk penelitian di Indonesia, tetapi hanya baru digunakan untuk penelitian di daerah sekitar daerah aliran sungai (DAS) saja (Amin, 2016; Raharjo, 2016; Sofan, 2014). Pengembangan penelitian yang ada di negara-negara lain dengan menggunakan metode SCS-CN ini juga terbukti dapat juga digunakan untuk daerah perkotaan (Yao, 2015; Zhang, 2015). Oleh karena itu, metode SCS-CN dianggap paling cocok untuk digunakan dalam penelitian di Kelurahan Rawa Buntu ini.

Secara keseluruhan sumber data yang digunakan pada penelitian ini merupakan data sekunder yang diambil dari berbagai sumber yang dapat dilihat pada Tabel berikut:

Tabel 1. Kebutuhan Data Untuk Penelitian di Wilayah Kelurahan Rawa Buntu (hasil analisis, 2018)

\begin{tabular}{|c|c|c|c|c|c|}
\hline No. & Data & $\begin{array}{l}\text { Bentuk } \\
\text { Data }\end{array}$ & Jenis Data & $\begin{array}{c}\text { Teknik } \\
\text { Pengumpulan } \\
\text { Data }\end{array}$ & Sumber Data \\
\hline 1. & $\begin{array}{l}\text { Luas Area } \\
\text { Tutupan } \\
\text { Lahan }\end{array}$ & Dokumen & $\begin{array}{l}\text { Data } \\
\text { Sekunder }\end{array}$ & $\begin{array}{l}\text { Studi } \\
\text { Dokumen }\end{array}$ & $\begin{array}{l}\text { Dinas Tata } \\
\text { Kota, } \\
\text { Bangunan, dan } \\
\text { Permukiman } \\
\text { Kota Tangsel }\end{array}$ \\
\hline 2. & $\begin{array}{l}\text { Data } \\
\text { permukiman }\end{array}$ & $\begin{array}{l}\text { Informan } \\
\text { Penelitian }\end{array}$ & $\begin{array}{l}\text { Data } \\
\text { Sekunder }\end{array}$ & $\begin{array}{l}\text { Studi } \\
\text { Dokumen }\end{array}$ & $\begin{array}{l}\text { Kelurahan } \\
\text { Rawa Buntu }\end{array}$ \\
\hline 3. & Nilai CN & Jurnal & $\begin{array}{l}\text { Data } \\
\text { Sekunder }\end{array}$ & $\begin{array}{l}\text { Studi } \\
\text { Kepustakaan }\end{array}$ & Literatur \\
\hline 4. & $\begin{array}{l}\text { Rerata Curah } \\
\text { Hujan }\end{array}$ & Dokumen & $\begin{array}{l}\text { Data } \\
\text { Sekunder }\end{array}$ & $\begin{array}{l}\text { Studi } \\
\text { Dokumen }\end{array}$ & BMKG \\
\hline
\end{tabular}

Data dan peta dan luasan tutupan lahan pada wilayah Kelurahan Rawa Buntu secara detail didapat dari Dinas Tata Kota, Bangunan, dan Permukiman Kota Tangerang Selatan, dimana data tersebut diolah dengan aplikasi sistem informasi geografis (GIS). Sedangkan data berupa peta demografi Kelurahan Rawa Buntu didapat dari Kantor Kelurahan Rawa Buntu. Untuk data nilai CN dan rerata curah hujan diambil dari jurnal yang merupakan data sekunder juga. Data tabel nilai $\mathrm{CN}$ yang digunakan pada penelitian ini merupakan nilai $\mathrm{CN}$ yang telah didapatkan dari hasil penelitian sebelumnya pada wilayah JABODETABEK, sedangkan data curah hujan didapat dari Badan Meteorologi, Klimatologi, dan Geofisika. Selain itu, Badan Penanggulangan Bencana Daerah Kota Tangerang Selatan juga memberikan informasi mengenai beberapa titik yang sering terbentuk genangan saat hujan di Kelurahan Rawa Buntu.

Teknik pengumpulan data yang dilakukan pada penelitian ini dilakukan dengan studi dokumen dan studi kepustakaan karena data yang digunakan dalam perhitungan merupakan data sekunder. Studi dokumen dilakukan untuk data yang didapat dari instansi terkait dan data bersifat tertutup. Sedangkan untuk kelengkapan perhitungan dilakukan juga pengumpulan data yang diperlukan dengan mencarinya dari publikasi buku dan jurnal terkait. Khusus untuk pengumpulan data luasan tutupan lahan disertai juga dengan kegiatan observasi lapangan untuk memastikan bahwa peta yang diberikan sesuai dengan kondisi nyata yang ada pada wilayah penelitian.

Hasil penelitian akan menunjukkan limpasan air hujan total yang dapat dikurangi oleh kondisi tutupan lahan di Kelurahan Rawa Buntu. Kapasitas total reduksi limpasan dihitung berdasarkan persamaan SCS-CN dengan data yang diperoleh dari observasi dan hasil studi literatur. Observasi perlu dilakukan untuk memastikan bahwa luasan lahan pada kawasan sesuai dengan kondisi yang ada (existing) pada wilayah penelitian, dalam hal ini Kelurahan Rawa Buntu. Sedangkan data dari studi literatur diperlukan untuk mendapatkan curah hujan rata-rata Kelurahan 
Rawa Buntu. Analisis data yang dilakukan untuk perhitungan volume reduksi runoff dengan metode SCS-CN ini merupakan analisis data secara kuantitatif yang dilakukan dengan menggunakan persamaan SCS-CN.

Selanjutnya analisis data kualitatif juga dilakukan untuk melihat seberapa besar dan signifikan peranan ruang terbuka hijau yang ada di Kelurahan Rawa Buntu dalam rangka mengurangi limpasan air hujan pada kawasan tersebut. Selain itu, analisis data secara kualitatif juga dilakukan dalam pemberian saran dalam melakukan upaya peningkatan dan optimalisasi reduksi runoff pada kawasan tersebut.

\section{HASIL DAN PEMBAHASAN}

\subsection{Kondisi Umum Wilayah}

Wilayah Kelurahan Rawa Buntu merupakan bagian dari wilayah Kecamatan Serpong, Kota Tangerang Selatan, Provinsi Banten. Secara geografis, Kantor Kelurahan Rawa Buntu berada di Jl. Raya Rawa Buntu No.121, Rw. Buntu, Serpong, Kota Tangerang Selatan, Banten 15310 RT 005 RW 02 tepatnya pada $6^{\circ} 19^{\prime} 4,62$ " LS dan $106^{\circ} 40^{\prime} 49,81^{\prime \prime}$ BT ($6.317950,106.680503)$. Pembagian wilayah kelurahan yang ada di Kecamatan Serpong dapat dilihat pada Gambar berikut:

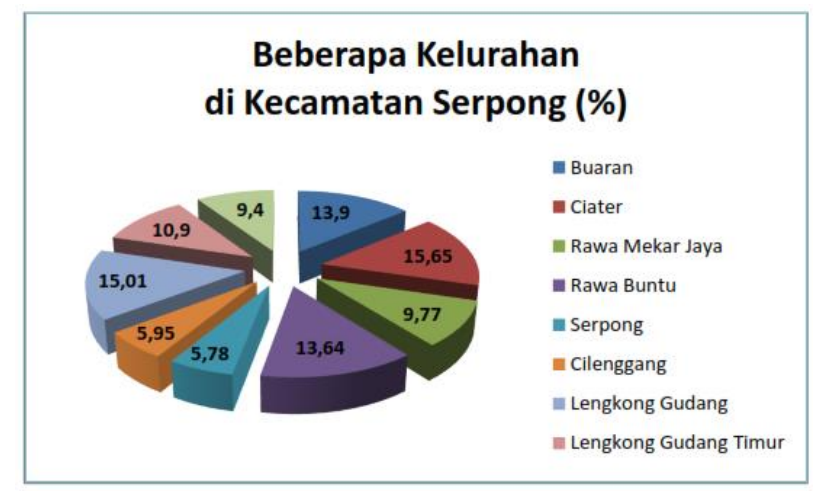

Gambar 1. Pembagian luas wilayah Kelurahan di Kecamatan Serpong (BPS Kecamatan Serpong, 2017)

Secara keseluruhan luas tanah di Kelurahan Rawa Buntu sebesar 328,62 hektar atau setara dengan 3,2862 km2. Sesuai dengan rencana awalnya, Kelurahan Rawa Buntu ini dikembangkan untuk kawasan permukiman yang dapat mendukung pertumbuhan penduduk dari ibukota Jakarta dan lebih dari sepertiga luas lahannya sekarang telah ditutupi oleh bangunan, baik bangunan permukiman, bangunan komersial, maupun bangunan lainnya. Sedangkan lahan lainnya berupa ruang terbuka hijau, jalan, lahan parkir, serta sarana dan prasarana publik lainnya. Lebih dari setengah wilayah Kelurahan Rawa Buntu merupakan kawasan permukiman beserta sarana dan prasarananya (seperti lahan parkir, halaman, dan lain-lain). Kawasan komersial juga dibuat dan dikembangkan untuk penunjang kehidupan masyarakat yang tinggal di Kelurahan Rawa Buntu yaitu sekitar $16 \%$ dari luas keseluruhan wilayah, seperti kawasan rekreasi, pertokoan, dan lain sebagainya. Sisanya diperuntukkan sebagai ruang terbuka hijau, baik itu berupa taman, makam, sempadan sungai, sempadan kereta api, maupun jalur penghijauan jalan. Selanjutnya yang perlu mendapat perhatian kita, yaitu luasan ruang terbuka masih sangat kurang hanya sekitar $17 \%$ saja dari luas total wilayah Kelurahan Rawa Buntu secara keseluruhan. Standar umum yang baik dari RTH pada suatu kawasan adalah sekitar $30 \%$.

Ruang terbuka hijau yang ada di Kelurahan Rawa Buntu terbagi dalam beberapa kategori. Sekitar $74 \%$ dari total RTH yang ada di Kelurahan Rawa Buntu ini berupa taman, dimana yang termasuk dalam kategori taman antara lain taman publik, taman privat, lahan kosong, jalur penghijauan jalan, maupun area penghijauan bangunan lainnya. Hal ini sangatlah wajar karena pada umumnya setiap kawasan atau kompleks permukiman pasti memiliki taman di dalamnya. Jadi karena keseluruhan dari Kelurahan Rawa Buntu ini memang didominasi oleh kawasan permukiman, tidaklah mengherankan apabila banyak terdapat taman-taman di kelurahan ini. Selanjutnya kawasan RTH yang berupa makam memang tidak terlalu luas, bahkan tidak mencapai 1\% karena makam di Kelurahan Rawa Buntu ini merupakan makam warga sekitar sehingga tidak terlalu luas. Sedangkan untuk RTH yang merupakan sempadan sungai dan sempadan rel kereta api memang tidak terlalu signifikan luasannya karena memang 
kawasan ini berbatasan dengan kelurahan lainnya yang ada di Kecamatan Serpong. Rincian pembagian RTH di Kelurahan Rawa Buntu dapat dilihat pada Tabel berikut:

Tabel 2. Rincian luas RTH Kelurahan Rawa Buntu (Dinas Bangunan dan Penataan Ruang Kota Tangsel, 2010)

\begin{tabular}{clcc}
\hline No. & Jenis RTH & Luas (ha) & Persentase (\%) \\
\hline 1. & Taman & 43,27 & 13,17 \\
2. & Makam & 3,05 & 0,93 \\
3. & Sempadan Sungai & 8,01 & 2,44 \\
4. & Sempadan Rel KA & 3,98 & 1,21 \\
\hline \multicolumn{2}{c}{ Total } & 58,31 & 17,74 \\
\hline
\end{tabular}

\subsection{Kondisi Tutupan Lahan}

Kondisi tutupan lahan di Kelurahan Rawa Buntu terbagi menjadi tiga kawasan, yaitu kawasan permukiman, kawasan perdagangan dan jasa, serta kawasan RTH. Secara keseluruhan, wilayah Kelurahan Rawa Buntu didominasi oleh kawasan permukiman, yaitu seluas 215,48 hektar atau sekitar $65,57 \%$ dari total luas wilayah Kelurahan Rawa Buntu. Kawasan RTH di Kelurahan Rawa Buntu memiliki luas sebesar 58,31 hektar atau sekitar $17,74 \%$ dari total luas wilayah Kelurahan Rawa Buntu. Sedangkan kawasan perdagangan dan jasa di Kelurahan Rawa Buntu memiliki luas sebesar 54,83 hektar atau sekitar $16,69 \%$ dari total luas wilayah Kelurahan Rawa Buntu.

\subsection{Kondisi RTH}

Ruang terbuka hijau total yang ada di Kelurahan Rawa Buntu memiliki luas sebesar 58,31 hektar. Dari total luas RTH yang ada, seluas 43,27 hektar berupa taman atau sekitar 74\%. Taman publik adalah RTH yang paling banyak terdapat di Kelurahan Rawa Buntu karena wilayah Kelurahan Rawa Buntu yang didominasi oleh kawasan permukiman, seperti taman-taman yang ada di setiap kawasan perumahan warga (Gambar 40). Ada pula beberapa lahan-lahan kosong yang terdapat di area permukiman warga, serta ada yang difungsikan sebagai kebun dan ditanami berbagai tanaman seperti singkong, ubi, dan lain-lain. Selain taman yang ada di area permukiman warga, jalur hijau yang ada di sepanjang jalan juga dimasukkan ke dalam kategori taman, baik jalan raya maupun jalanjalan di kompleks perumahan.

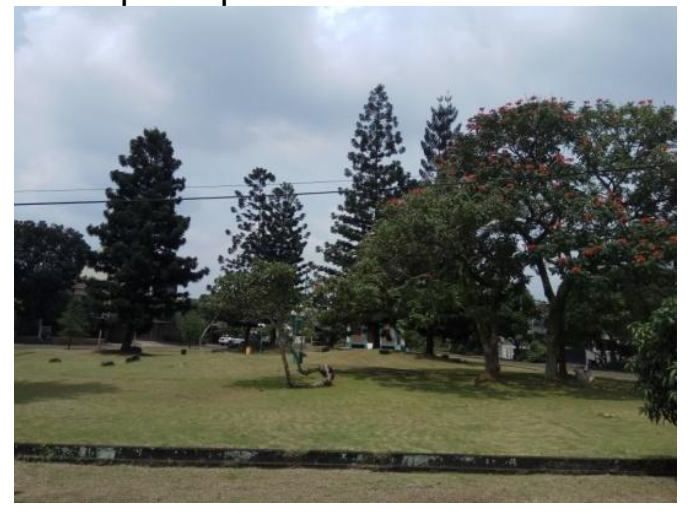

Gambar 2. Taman Kompleks Perumahan (Dokumengtasi, 2018)

Jenis RTH lain yang ada di Kelurahan Rawa Buntu adalah sempadan kereta api. Luas sempadan kereta api yang ada di sepanjang rel kereta api Rawa Buntu adalah 3,98 hektar atau sekitar $7 \%$ dari total luas RTH di Kelurahan Rawa Buntu.

\subsection{Hasil Perhitungan Reduksi Limpasan Air}

Data yang digunakan dalam perhitungan reduksi limpasan air hujan dengan metode SCS-CN antara lain data luas masing-masing tutupan lahan di Kelurahan Rawa Buntu, data curah hujan di Kelurahan Rawa Buntu, dan nilai CN untuk masing-masing tutupan lahan di Kelurahan Rawa Buntu. Detail data tutupan lahan ini diperoleh dari citra satelit tahun 2010 yang dimiliki oleh Dinas Bangunan dan Penataan Ruang Kota Tangerang Selatan. Sistem Informasi Geografis (GIS) sudah dipergunakan oleh Dinas Bangunan dan Penataan Ruang Kota Tangerang Selatan untuk memperoleh data luasan yang lebih akurat. Data curah hujan yang digunakan diperoleh dari Badan Meteorologi, Klimatologi, dan Geofisika tahun 2013. Sedangkan data nilai CN untuk tutupan lahan kawasan penelitian didapatkan dari penelitian sebelumnya dalam bentuk jurnal. Berikut ini merupakan detail proses perhitungan reduksi limpasan air hujan 
pada wilayah Kelurahan Rawa Buntu dengan metode SCS-CN.

Selanjutnya dari hasil perhitungan, kita dapat melihat bahwa pada kondisi saat ini apabila dikonversikan ke dalam satuan miliar galon Kelurahan Rawa Buntu dapat mereduksi volume runoff sebesar $74,4 \mathrm{MGal}$ dalam kurun waktu 1 bulan saat kondisi $\mathrm{AMCl}$, yaitu saat kondisi kering. Tren menunjukkan bahwa semakin basah kondisi kelembaban tanah, maka kemampuan reduksi runoff pun semakin menurun, dimana volume runoff yang dapat direduksi pada kondisi AMCII dan AMCIII berturut-turut dalam kurun 1 bulan adalah 37,8MGal dan 17,9MGal. Hal ini terjadi karena pengaruh kejenuhan air tanah pada wilayah tersebut. Pada saat kondisi kelembaban awal basah, runoff yang dapat ditampung dan diresapkan ke dalam tanah tentu lebih sedikit bila dibandingkan pada kondisi kelemababan awal yang normal maupun kering. Pada saat kondisi basah, tanah sudah mengalami masa jenuh karena sudah mengandung banyak air, sehingga sisa volume yang dapat ditampung akan lebih sedikit apabila dibandingkan dengan kondisi tanah yang tidak jenuh pada masa kering.

Hasil perhitungan juga menunjukkan bahwa ruang terbuka hijau yang ada pada wilayah penelitian memiliki peranan yang signifikan dalam mengurangi volume runoff pada wilayah tersebut. Pada kondisi $\mathrm{AMCl}$, RTH terbukti memberikan kontribusi sebesar $27 \%$ dari total volume runoff yang dapat direduksi pada kawasan Kelurahan Rawa Buntu. Mengingat luasan RTH yang dapat dibilang cukup minim pada kawasan yakni hanya $17 \%$ dari luasan total kawasan, maka peran dari RTH ini cukup signifikan dan terbukti mempunyai andil yang cukup besar dalam mereduksi limpasan permukaan pada kawasan tersebut. Pada kondisi AMCII, besar kontribusi yang diberikan oleh RTH dalam mereduksi runoff kawasan semakin terlihat, dimana dapat mengurangi runoff sebesar $31,2 \%$ dari total volume runoff yang dapat direduksi oleh keseluruhan kawasan. Sedangkan pada kondisi AMCIII, kontribusi RTH semakin besar lagi yaitu mampu mengurangi runoff sebesar $36,4 \%$ dari total runoff yang dapat direduksi oleh kawasan.
Peranan dari ruang terbuka hijau terhadap reduksi runoff kawasan akan semakin terlihat dalam kondisi kelembaban tanah yang basah. Hal ini terjadi karena walaupun dalam kondisi tanah jenuh dan kuantitas reduksi volume pun menurun, namun kemampuan ruang terbuka hijau dalam meresapkan air hujan ke dalam tanah tetap jauh lebih efektif bila dibandingkan dengan tutupan lahan lain yang lebih kedap air (impermeable), sehingga pada kondisi inilah akan semakin terlihat peranan RTH yang sangat signifikan dalam mengurangi limpasan permukaan yang ada di wilayah perkotaan.

\subsection{Reduksi Volume Limpasan Air}

Perhitungan dilakukan dengan menggunakan rerata curah hujan setiap bulan pada tahun 2013 di Kelurahan Rawa Buntu. Secara keseluruhan hasilnya memperlihatkan bahwa pada kondisi kering (AMC I) tutupan lahan di Kelurahan Rawa Buntu mampu mereduksi volume limpasan air hujan lebih banyak dibandingkan dengan kondisi normal (AMC II) dan kondisi basah (AMC III). Hal itu disebabkan karena kondisi air di dalam tanah sudah jenuh, jadi tidak ada lagi limpasan air yang dapat diserap, khususnya oleh tutupan lahan berupa RTH. Grafik pada Gambar 45 juga menunjukkan bahwa semakin tinggi tingkat curah hujan, maka semakin besar juga potensi reduksi limpasan air hujannya.

\section{SIMPULAN}

Berdasarkan hasil dan pembahasan yang telah dipaparkan sesuai dengan tujuan penelitian pada bab iv, maka didapatkan kesimpulan sebagai berikut:

1. Total volume air limpasan (run off) yang dapat direduksi berdasarkan kondisi tutupan lahan yang ada di Kelurahan Rawa Buntu berbeda-beda dan sesuai dengan kondisi AMC yang terjadi, dimana pada kondisi $\mathrm{AMCl}$ (kering) tutupan lahan existing dapat mereduksi runoff sampai dengan 74,4MGal dalam kurun waktu 1 bulan. Sedangkan untuk AMCII dan AMCIII masing-masing dapat mereduksi volume 
runoff sebesar 37,8MGal dan 17,9MGal dalam kurun waktu yang sama.

2. Peranan ruang terbuka hijau terlihat cukup signifikan dalam mengurangi air limpasan (run off) pada wilayah Kelurahan Rawa Buntu. Semakin basah kondisi kelembaban awal tanah, maka peranan dari RTH dapat terlihat semakin besar dan jelas. Adapun persentase kontribusi RTH dalam mengurangi runoff kawasan pada $\mathrm{AMCl}$, AMCII, dan AMCIII semakin meningkat pada kondisi semakin basah adalah $27 \%, 31,2 \%$, dan $36,4 \%$ dari total runoff kawasan Kelurahan Rawa Buntu.

\section{REFERENSI}

Amin, M. Baitullah Al. 2016. Analisis Genangan Banjir di Kawasan Sekitar Kolam Retensi dan Rencana Pengendaliannya, Studi Kasus: Kolam Retensi Siti Khadijah Palembang. Jurnal Perencanaan Wilayah dan Kota, 27 (2), 69-90.

Andini, Febby Ekamukti, Yulisa Fitrianingsih, dan Agus Ruliyansyah. 2016. Evaluasi Fungsi Ekologis Ruang Terbuka Hijau (RTH) Perkotaan Sebagai Areal Resapan di Kota Pontianak (Studi Kasus: Taman Alun Kapuas). Jurnal Mahasiswa Teknik Lingkungan UNTAN, 1 (1), 1-10.

Arsyad, Sitanala dan Ernan Rustiadi. 2012. Penyelamatan Tanah, Air, dan Lingkungan. Jakarta: Crestpent Press dan Yayasan Pustaka Obor Indonesia.

Asdak, Chay. 2010. Hidrologi dan Pengelolaan Daerah Aliran Air Sungai: Edisi Revisi Kelima. Yogyakarta: Gadjah Mada University Press Yogyakarta.

Badan Pusat Statistik. 2006-2017. Jakarta dalam Angka 2006-2017. Jakarta: Badan Pusat Statistik Provinsi DKI Jakarta.

Butler, David, dan Davies, John W. 2011. Urban Drainage 3rd Edition. New York: Spon Press.

Chow, V.T. 1964. Handbook of Applied Hydrology: a Compendium of WaterResources Technology. New York: McGraw-Hill Companies.
Chow, V.T. 1964. Handbook of Applied Hydrology: a Compendium of WaterResources Technology. New York: McGraw-Hill Companies.

Day, C. Andrew dan Keith Allen Bremer. 2013. Modeling Urban Hydrology: A Comparison of New Urbanist and Traditional Neighborhood Design Surface Runoff. International Journal of Geosciences, 4 (5), 891-897.

El-Hames, A. S. 2012. An empirical method for peak discharge prediction inungauged arid and semi-arid region catchments based on morphological param-eters and SCS curve number. Journal of Hydrology, 456-457, 94- 100.

Khaqim, Luqman dan Kwardiniya A. 2013. Proyeksi Penduduk Provinsi DKI Jakarta dan Kota Surabaya dengan Model Pertumbuhan Logistik. Jurnal Mahasiswa Matematika, 1 (3), 232-235.

Palar, Ronaldo Toar, dkk. 2013. Studi Perbandingan Antara Hidograf SCS (Soil Conservation Service) dan Metode Rasional Pada DAS Tikala. Jurnal Sipil Statik, 1 (3), 171-176.

Ponce, Victor Miguel. 1989. Engineering Hidrology: Principles and Practices. New Jersey: Prentice Hall.

Undang-Undang Republik Indonesia. 2007. Penataan Ruang (nomor 26 Tahun 2007). Jakarta: Presiden Republik Indonesia.

Zhang, B., dkk. 2015. Effect of urban green space changes on the role of rainwater runoff reduction in Beijing, China. Landscape and Urban Planning, 140, 816. 